\title{
“That German Stuff”: Negotiating Linguistic Legitimacy in a Foreign Language Classroom
}

\author{
Johana Ennser-Kananen \\ University of Jyväskylä

\begin{abstract}
Correspondence concerning this article should be addressed to Johana Ennser-Kananen, Department of Language and Communication Studies,Centre for Applied Language Studies, PO Box 35, University of Jyväskylä, Finland, 40014. E-mail: johanna.f.ennser-kananen@jyu.fi
\end{abstract}

\begin{abstract}
This qualitative case study of one German suburban high school classroom in the Midwestern United States examines how learners of German negotiate their linguistic legitimacy, which is defined as discursively constructed acceptance or validation for their language use. Specifically, it investigates how the students negotiated legitimacy for using their target language German in their classroom. Based on the premise that linguistic legitimacy is crucial for the maintenance and development of speakers' languages, data was collected by employing classroom recordings, semi-structured interviews, and participant observations. Findings revealed that, while English dominated the lessons as the default legitimate language among the students, using German was accepted and valued under certain circumstances. Such instances of linguistic legitimacy included the use of German for entertainment or in role plays, a pattern which points to the students' desire to mitigate investment and display "uninvestment" in learning or using German. Implications for foreign language (FL) pedagogy and teacher education are discussed.
\end{abstract}

Keywords: foreign languages, language learning, linguistic legitimacy, German foreign language (FL), foreign language (FL) pedagogy

For language learners, engaging in conversations with first language (L1) speakers can be daunting, as the weight of language ideologies - for example the notion that L1 speakers are the only rightful users of a language - bear down on them and can impede their willingness to use that language (e.g., Norton, 2000; Pomerantz, 2002). This, in turn, can limit students' language output and thus interfere with their target language development (Swain, 1995). Given the relatively low performance of U.S. high school students in the acquisition of foreign languages (FL) - most only reach novice-high or intermediate-low levels within a four-year FL program, regardless of the language (CASLS, 2010) - obstacles like this, which stand in learners' ways to high FL proficiency, cannot be ignored.

This paper offers an analysis of the experience of language-majority learners of German in a US high school classroom as they were balancing societal power structures, the teacher's expectations, and their relationships with their peers. More specifically, it examines their (in)ability to establish a sense of acceptance and validation for their practice of using German, or their linguistic legitimacy as learners of German. In order to promote language learners' language use and development, it is crucial to gain an understanding of how students do (not) establish linguistic legitimacy as language learners and identify strategies to promote their linguistic legitimacy.

\section{Literature Review}

Linguistic legitimacy. In this study, I viewed interaction in a foreign language (FL) classroom through the lens of linguistic legitimacy. In the following section, I briefly introduce the theoretical foundations of this work, the concepts of investment, legitimate language, and legitimation. Linguistic legitimacy draws on both notions, but also extends them in important ways. The concept discussed here is distinct from "linguistic legitimacy" as defined by Reagan (2016), who understands linguistic legitimacy as unjust and unjustified claim of the superiority of one language over another one. Although my stance 
is similar in that I aim to uncover and challenge discriminatory ideologies, linguistic legitimacy as I understand it refers to the acceptance and validation of a linguistic practice that is negotiated in discourse.

Foundations of linguistic legitimacy: Investment. Linguistic legitimacy is closely related to Norton's work on investment (e.g., Darvin \& Norton, 2015; Norton, 2000, 2013; Norton Pierce, 1995), which, from its beginnings in the 1990s, has evolved into an influential line of scholarship in applied linguistics that spans a wide range of disciplines and contexts (see Pittaway, 2004 and Darvin \& Norton, 2015). In her well-known critique of Second Language Acquisition (SLA) theory at that time, Norton shifted the focus of the field from learner-immanent characteristics to contextual processes that influence language learners' commitment to and/or engagement in the learning process. As Norton (2013) explains,

[t]he construct of investment offers a way to understand learners' variable desires to engage in social interaction and community practices ... [I]t signals the socially and historically constructed relationship of learners to the target language and their often ambivalent desire to learn and practice it. If learners 'invest' in the target language, they do so with the understanding that they will acquire a wider range of symbolic resources (language, education, friendship) and material resources (capital goods, real estate, money), which will in turn increase the value of their cultural capital and social power (p. 6).

Norton points out that learners' investment occurs in anticipation of resources that eventually contribute to their gains of cultural capital and power. The possibility for acquiring these resources, and consequently the degree of investment, is in part dependent on the perceived or declared value of learners' language practices in a particular context, in other words, on the linguistic legitimacy language learners negotiate with their environment.

I argue that the concepts of investment and linguistic legitimacy shed an important light on aspects of FL education in the U.S. Rather than subscribing to popular arguments that explain U.S. students' lack of FL competencies with a lack of motivation, it would make for a more fruitful debate if we, like Norton, insisted that a motivation orientation does not suffice to address this problem. This study sets out to describe FL learners' linguistic legitimacy and identify strategies to increase it.

It is important to note that the concept of investment cannot be applied uncritically to foreign language contexts. Most learners of German or other foreign languages in U.S. high school classrooms certainly do not face the same pressure to acquire "a wider range of symbolic resources (language, education, friendship) and material resources (capital goods, real estate, money)" (Norton, 2013, p. 6) as the learners in the foundational studies on investment. However, just like Norton's (2000) participants, whose investment depended on conversational opportunities they were granted by first language (L1) speakers of English, the students in this study had to negotiate entry into new linguistic and cultural communities and sought to acquire resources that would facilitate this entry.

Foundations of linguistic legitimacy: Legitimate language and legitimation.-The present study focused on the opportunities for target language use that FL learners negotiated within a German classroom. It asked how their use of German was interactively accepted or validated within this context, how learners were (or were not) able to negotiate this validation or acceptance, in essence, how the students were able to be or become speakers of a "legitimate language" (Bourdieu, 1977, p. 650). Although several scholars have developed the concepts of legitimate language and discursively constructed legitimation, as noted by Norton (1995), the foundation for the concept was laid by Bourdieu, who defines it as follows:

[I]t is uttered by a legitimate speaker, i.e. by the appropriate person ...; it is uttered in a legitimate situation, i.e. on the appropriate market ... and addressed to legitimate receivers; it is formulated in the legitimate phonological and syntactic forms (what linguists call grammaticalness), except when transgressing these norms is part of the legitimate definition of the legitimate producer (Bourdieu, 1977, p. 650 , emphasis removed).

Bourdieu addresses a critical aspect of legitimacy, its contingency on context. Thus, legitimacy is not intrinsic to a language but contextually and socially constructed and dependent on the alignment of speaker, receiver, situation, and linguistic form to what is deemed socially acceptable and appropriate in a particular context.

Heller's work (1995, 1996, 2006) emphasizes another important aspect of legitimate linguistic practices, their dynamic nature. In her sociolinguistic ethnography of a Toronto school, she documents how ideas of what is a legitimate language at school can shift and depend on the social power structures in a particular context. For example, the Francophone Canadians in her study, while advocating for their own linguistic legitimacy in an English-dominant context, push speakers of Canadian French vernaculars and 
migrant students to the margins of legitimacy, thus indicating the ever-shifting nature and powerladenness of linguistic legitimacy.

Van Leeuwen uses his concept of legitimation, the process through which legitimacy is discursively claimed, to analyze political speeches on migration and unemployment (Van Leeuwen \& Wodak, 1999; Wodak \& Van Leeuwen, 2002). According to him, legitimation occurs in four different ways, as: (a) authorization, the speaker's reference to a personal or impersonal authority; (b) moral evaluation, the invoking of a particular set of values; (c) rationalization, such as through the speaker's emphasis on purposes or goals; and (d) mythopoesis, the quoting of narratives (Van Leeuwen, 2007, 2008).

The present study builds on the existing work by Bourdieu, Norton, Heller, and Van Leeuwen, who emphasize the contextuality and dynamic nature of legitimate linguistic practices. However, they do not provide an analysis of how linguistic legitimacy is negotiated in discourse. Van Leeuwen's work, for instance, focuses on legitimation as legitimacy claims. However, when legitimacy is claimed, it can and often does undergo a process of negotiation or even rejection, which can be interactively repeated and rescripted. It is important to understand these processes of negotiating linguistic legitimacy in order to understand and influence how power and resources are distributed.

In contrast to Van Leeuwen's theory of legitimation, the present study seeks to understand how legitimacy is interactively claimed, negotiated, and constructed. In addition, it differs from Van Leeuwen's concept in that it focuses specifically on the legitimation of linguistic practices. Specifically, it asks how FL learners construct linguistic legitimacy for (not) speaking German in their classroom. Rather than examining institutional-level shifts in linguistic legitimacy like Heller's study, this study analyzes legitimacy negotiations in classroom interaction.

\section{Classrooms as Sites of Legitimacy Negotiations}

Language classrooms are characterized by overt or covert language policies which often identify a societal or school-wide language or variety as the norm and, as a consequence, may consider those who do not abide by this norm to be deficient. In these environments, establishing linguistic legitimacy is often synonymous with adapting to the dominant linguistic norm, and failure to adapt can be met with social and/or academic sanctions. As Bourdieu (1977) already pointed out, what is linguistically legitimate (language) relates to who receives legitimacy (speaker) and thus oftentimes becomes a matter that is examined within the framework of language users' identities (e.g., Pavlenko \& Blackledge, 2004).
Many examples of negotiated and negotiating language learner identities come from second language (L2) learning contexts or bilingual education contexts with students from a minoritized-language background. In these settings, learners seek to acquire the societally dominant or powerful language, which is often presented to them or imagined by them as a direct pathway to the acquisition of social and cultural capital (Norton, 2013).

For example, Leki (2001) and Morita (2004) analyze opportunities and failed attempts of English learners (ELs) to participate in lesson activities "as legitimate and competent members of their classroom communities" (Morita, 2004, p. 573) within their U.S. American and Canadian schools. Similarly, work by Chen (2010) and Talmy (2008) examine how English learners rejected the narrow and low-status identities that the school had reserved for them and carved out spaces of increased legitimacy for themselves.

As language learners seek to improve their status through the languages they learn, the roles of both teachers and students in this process have been highlighted. Teachers participate in deciding what is linguistically legitimate in educational contexts and thus can be complicit in the production of restrictive discourses around secondlanguagelearners'legitimacy. For example, based on his analysis of Turkish-heritage youth's linguistic practices in Germany, Hinnenkamp (2005) reported on teachers referring to these practices as "double semilingualism" (pp.57-58), suggesting that they speak neither Turkish nor German in a proficient or legitimate way. Hinnenkamp calls for a recognition of migrant youth's "linguistic code in its own right" (p. 15) and highlights the important role teachers could play in legitimizing these linguistic codes. Palmer's (2008) examination of interactions in a second grade two-way English-Spanish immersion classroom in California showed that teachers can support language minoritized students by helping them build positive academic identities claim space and legitimacy for their language practices.

In addition to teachers, students have also been shown to drive legitimation processes. For instance, De Costa (2011) reports that "Jenny," an English learner, legitimized herself as a proficient speaker of academic English by distancing herself from "Singlish" (p. 353) and instead engaging in "literate talk" (p. 354). Although this process that can be seen as empowering, it points to a problematic dynamic that pressures language-minoritized students to adapt to normative discourse that may ultimately harm their multilingual development and identities.

All these studies illustrate how L2 learning is a site of negotiation for legitimacy. In this paper, I argue that this notion can also be applied to the foreign language classroom. 


\section{Linguistic Legitimacy in Foreign Language Contexts}

As Kinginger (2004) has pointed out, foreign language classrooms have not traditionally been described as spaces where identity work is common or necessary, which is certainly also true for legitimacy. One problematic assumption seems to be that foreign language learners, who, in the U.S. K-12 context, are taught in classrooms populated predominantly by white middle-class children and youth, acquire foreign language as a skill that does not require them to re-imagine their identities but is merely added onto their already legitimate identities as members of the dominant social group. For instance, a U.S.-born white high school student learning French is rarely thought of as a language learner who has to negotiate the "right to speak" the target language or undergo identity shifts and negotiations throughout the acquisition process in contrast to a second language learner, whose social status and relationships are heavily dependent on the ability to establish linguistic legitimacy.

It is important to point out the unique role English as a foreign language (EFL) education plays in this respect. The majority of studies that address FL learners' identities or legitimacy stem from EFL contexts where English plays a dual role: on the one hand, it is identified, problematically, as languagesina-qua-non, an essential skill and door-opener to professional success (e.g., Kubota, 2011; Park, 2010). On the other hand, it is also a tool of empowerment and agency that allows learners to reinvent themselves (Gao, Cheng \& Kelly, 2008; Gu, 2008; Trent, 2008). Due to this status of English as power language and empowering language, the negotiations of power, cultural capital, and identities that have been described in EFL contexts resemble those that have commonly been reported in ESL environments. Such negotiations are not typically associated with learning less dominant foreign languages in traditional settings, like French or German FL classrooms in the U.S. Despite the prominent role of identity-related scholarship in heritage language, indigenous, and postcolonial contexts, traditional FL education seems hesitant to catch on. The neglect of non-English FL classrooms in this line of scholarship is evidence of a rather limiting view of foreign language education: foreign languages are not commonly associated with negotiations of identities or legitimacy as language users.

Few studies have challenged the view of FL education as a space that is void of identity and legitimacy negotiations. For example, Pomerantz (2002) has shown how language use interacts with academic student identities. She analyzes the language ideologies and academic identities of U.S. college students in an advanced Spanish course, focusing on how her participants enacted and negotiated good language learner (GLL) identities. Examples from classroom discourse showed that using English or not knowing a Spanish word in the classroom could be a serious threat to one's GLL identity and result in being identified as incompetent and illegitimate Spanish speaker. Pomerantz' study illustrates how students created their "right to speak" (Norton, 2000) or linguistic legitimacy by drawing on linguistic ideologies and constructing social hierarchies in an FL learning environment.

Another rare examination of foreign language learning through the lens of identity construction is Kinginger's (2004) four-year study of "Alice", which analyzes the experience of an American woman in the U.S. who immerses herself in French learning endeavors at home, in Quebec (four weeks), and France (two years) in order to advance her cultural competence and consciousness. Kinginger's analysis of the process, during which Alice negotiates and reconstructs her "social and linguistic, but also gender and class identity" (p. 240), demonstrates how FL learning can deeply affect and drive FL learners' ways of being in the world.

In addition, Rampton has made important contributions to the emerging scholarship of FL learning and identity construction. His work on language crossing (e.g., 1999, 2014) analyzes how students legitimately used foreign languages and linguistic features (stylized Asian English, Creole, and Panjabi)forvarious purposes includingrelationshipand identity building. In addition, his analysis (Rampton, 2006) of the language practices of multiethnic working-class youth in "Central High", an urban British secondary school, show how students not only appropriated a foreign language, but also reorganized classroom hierarchies by doing so. Rampton's work counters the traditional sociolinguistic perspective that perceives foreign language communities as remote and thus insignificant to students' social identities (e.g., Trudgill \& Giles, 1983, cited in Rampton, 2006). He found a considerable amount of German chunks in his participants' speech in and beyond the German classroom. For example, students used performances of impromptu German to signal shared meaning among themselves, mock teachers, establish a sense of collectiveness, and interrupt the rigid Initiation-Response-Evaluation (IRE) discourse of the German classes. Research outside of school contexts, for example in the Montreal HipHop community, has further highlighted how youth challenge and adapt language norms and policies (e.g., using "Good French", see Low, Sarkar \& Winer, 2009 , pp. 65ff). The latter works along with Rampton's studies powerfully illustrate that the legitimacy of 
foreign language practices is subject to processes of negotiation and appropriation informed by students' own social, academic, and communicative needs.

In all, although foreign language contexts have begun to be discovered as spaces of identity and legitimacy negotiation, no studies to date have investigated how FL learners construct spaces for their legitimate language use and negotiate their "right to speak" (Norton, 2000) the language they learn, i.e. their target language. Only by knowing how they do this can we leverage their existing strategies and develop methods for teachers and students to claim and negotiate legitimacy for their language use. Unless language learners are able to establish this linguistic legitimacy, their opportunities for using and developing their target languages will be severely restricted.

Therefore, the present study poses the following overarching research question: How do high school students in one German classroom negotiate linguistic legitimacy for their languages in their classroom? Focusing specifically on the students' target language use, this question contains the following sub-question: How do students negotiate and create linguistic legitimacy for using German? The following section provides an overview of how data was collected and analyzed in seeking to answer these two questions.

\section{Materials and Methods}

The data presented here was gathered during a semester-long qualitative case study of a German FL classroom at a U.S. Midwestern suburban high school. Ethnographic methods (see below) were employed to gather interactive constructions of linguistic legitimacy in this classroom.

At the time of data collection, Clearwater High School (a pseudonym) served a population of 1183 students, 60 of whom were enrolled in the German program. Spanish, Mandarin, and American Sign Language were also offered. The teacher, Frau Zeller (a pseudonym) was in her fifth year of teaching German and had been an ESL teacher for 10 years before accepting the position in the German Department. She was the only full-time German teacher at this school and taught German to a group of 34 students every morning from 7.30 to $8.20 \mathrm{am}$. The students were in their $3^{\text {rd }}$ or $4^{\text {th }}$ year of learning German. Three spoke home languages other than English (two Latvian, one Hmong), and all the other students identified English as their first language. As I have noted elsewhere in more detail (Ennser-Kananen et al., 2016), some of the students reported learning German in order to connect with their familial heritage, while others were hoping to set themselves apart from the majority of students who chose to learn Spanish.

As in an earlier study in a very similar setting (Ennser-Kananen, 2012), I used video and audio recordings, participant observation, and open-ended, semi-structured interviews to gather information about how students construct and negotiate their linguistic legitimacy in this German classroom. Visiting the classroom two to five times a week for one to five hours throughout one semester amounted to a total of approximately 145 hours of observations. As a participant observer, I engaged in classroom conversations with the participants, walked up and down the hallways with them, and occasionally joined them for lunch. I interviewed 32 of the 34 students as well as the teacher, on topics revolving around their language learning experiences, classroom activities, and language use. I recorded approximately 38 hours of classroom time, with approximately twice as much footage due to multiple camera use. These recordings gave me important insights into the moment-bymoment negotiations of linguistic legitimacy that occurred during German class. I kept a field log of my daily observation notes and transcribed data from interviews and classroom recordings.

About a third of the data underwent a process of open coding (Corbin \& Strauss, 2015) which produced 26 initial codes, each with two to six sub-categories. Throughout the deductive coding process, I collapsed these codes and the corresponding data into 10 larger themes in order to obtain answers to the research questions.

\section{Results and Discussion}

Findings revealed that, while German was not the legitimate linguistic norm among the students in the classroom, they accepted and even valued it under certain circumstances.

\section{The Illegitimacy of German}

As the data analysis showed, German was rarely identified as a legitimate linguistic practice among the students in the classroom. Rather, English was the default language. This is evidenced by the following excerpts, which are examples of typical interactions in this classroom.

In the first one, three students were collaborating on the task of comparing their homework, which was to fill in the blanks in a cloze activity with the appropriate words labeled $a-j$. The conversation consisted almost entirely of students reading aloud the letter of the respective answer as they filled in each slot. (Italics 
indicate that words or sentences have been translated from German. For better readability, only students who spoke three times or more in on excerpt were given names. Numbers (S1, S2 ...) represent different students in different excerpts. For more transcription conventions, please refer to the Appendix.)

Example 1: What you got?

1. T: Now, you should read the text in the group and compare the answers,

2. now, in the group, first read, read aloud and then compare answers.

3. S1: Mkay, so first one. I got e.

4. S2: Yeah.

5. S1: First this and, second one, I got c.

6. S2: That's what I got.

7. S3: Yeah.

8. S2: \{I got b.

9. S1: What you got? Second one?\}

10. S2: B yeah.

11. S1: I got c 'cause I thought that the third one would be b 'cause it makes,

12. she can't use, she isn't allowed to use her dad's car.

13. S2: Yeah, that's right.

14. S1: And uhm fourth one, I got, I uhm, and fifth one I got d, yeah.

15. S2: Then?

16. $\mathrm{S} 1: \mathrm{H}$, yeah, then $\mathrm{f}$ and $\mathrm{j}$ for the last one. Okay, so I got for, I got e, c, b, i,

17. $d, h, f, j$.

18. S2: Okay.

(Classroom recording, October 3, 2012)

What is noteworthy in this excerpt is that all students seemed to be in agreement with the unspoken rule of using English. Despite Frau Zeller's (T) instructions, which were given in German and asked the students to read the German text out loud, they chose to complete the task by reading merely the letter that corresponded to each answer in English. This could be due to the students' attempt to be efficient and goal-oriented, which would also explain their use of minimal English characterized by deixes, staccato rhythm, and the repetition of short and simple chunks ("I got"). In lines 11-12, S1 deviated from this efficiency policy. When more input became necessary because S1 and S2 had different answers, S1 provided a summary/translation of the German sentence from the text. Given the students' familiarity of the text and the fairly low linguistic and cognitive level of the task, ensuring understanding might not have been the main reason for this language choice. In addition, as the false starts in lines 11 and 12 signal, translating/ summarizing the sentence was apparently not the most efficient way of communicating. Thus, it seems that the students' unspoken policy of using English overruled their wish to be efficient in this moment.

In contrast to the youth in Rampton's (2006) study, in this instance, the Clearwater students refrained from appropriating German for their own purposes. Rather, their shared reluctance to deviate from the default English identified English as the legitimate language in this situation. The resulting illegitimacy of German was further consolidated in instances where being good at or being invested in learning German were marked as unacceptable.

In example 2, four students collaborated to list the responsibilities of a soccer coach. The extract stems from the beginning of their conversation, in which one student rejected the idea of being "good at that German stuff":

Example 2: That German stuff

1. S1: Okay, so what are we doing?

2. S2: We're writing a list, a to-do list for a football coach.

3. S3: Soccer.

4. S2: Soccer coach.

5. S1: Get the balls. [laughs]

6. S3: Okay, do you know how to say that?

7. S1 [to S2]: Do you know how to say that? You're quite good at that German stuff.

8. S2: Whaaat? [shakes head angrily]

9. S4: [eagerly]: Yeah, yeah you are.

(Classroom recording, October 3, 2012)

In this excerpt, $\mathrm{S} 2$, who at the time of data collection was indeed one of the most fluent German speakers in the class, was identified by S1 as being "quite good at that German stuff" (line 7), an identification $\$ 2$ rejected, but S4 confirmed. S1's choice of words ("that German stuff") and S2's reaction suggest that, at least in this moment, being an invested German student was not valued. Insofar as they delegitimized "good language learner" identities (Pomerantz, 2008), the students in this example went beyond defining legitimate language practices. Delegitimations like this one of either using German or showing investment in learning it occurred frequently throughout the semester, which suggests that the illegitimacy of German among the students was not only momentary, but rather indicative of an established classroom norm, that of using English and avoiding German as well as avoiding the public perception of being invested in learning it.

Interestingly, this contrasts with language learners in previous studies; for example, Jenny (De Costa, 2011), Evan (Chen, 2010) and participants in Pomerantz' (2008) study, all of whom claimed or constructed positive student identities by displaying or striving for high proficiency or high investment. While identifying English as the default legitimate language, data also showed that this norm was suspended in particular situations, especially when narrow spaces 
for language output were clearly defined, during role plays, and for the purpose of entertainment.

\section{The Legitimacy of German}

Under particular circumstances, speaking German was legitimate for the students in Frau Zeller's classroom. In these moments, students deviated from their unspoken English policy and often appropriated classroom discourse for their own purposes, similar to the youth in Rampton's (2006) work.

Vocabulary or grammar practice thinly disguised as communicative activities was a common occurrence in Frau Zeller's classroom and was usually highly scaffolded. For example, in order to practice the structure "was fürein(e/es)" [what kind of], she provided sentence frames, on the board as well as orally, which left very limited slots (for one verb and one noun) for the students to fill in. In the following excerpt, six students were performing the required conversation. (Italics mark translations from German, bold print marks language that was provided by the teacher.)

Example 3: What kind of?

1. S1 [to S2]: What kind of music do you listen to?

2. S2: [unintel.] Uhm, I have no idea. [Not rap, and I have a little bit of German

3. S4 [to S3]: What kind of sport do you do?\}

4. S2: Music [unintel.] and a little, little, little, little, bit rap.

5. $\{[$ All laugh. $]$

6. S2: Little, little, little.] Uhm and I [unintel.]

7. S3: I don't like* sport but I like going for walks, $h m$.

8. S1 [to S3]: What kind of pizza do you like to eat?

9. S3: Uhm all* pizza.

10. S1 [to S3]: Uhm what kind of music \{do you like to listen to?

11. S3: Uhm classic* rock\}

12. S2: What kind of uhm what kind of instruinstrument do you like to play?

13. S5: Saxophone.

14. S2: Okay.

15. S3 [to S6]: Hello, uhmuhmuhm, what kind of* film do you like to watch?

16. S6: Uhm [unintel.]. What kind of book do you like to read?

17. S3: Uhm I like realistic fiction and uhm [unintel.]. (Classroom recording, October 8, 2012)

Although during group work English was usually the legitimate language among the students, minidialogues like the one above were often performed in German if Frau Zeller provided extensive linguistic support. In these cases, the teacher's instructions acted as what Trent (2008) termed "tightly controlled script" (p. 37), an over-scaffolded framework that leaves very little space for student output. Such scripts seemed to have two effects: (a) they minimized the linguistic effort students needed to make to complete a task in German; (b) they helped them to participate in the activity without displaying much investment in learning German. Given the previous observations about illegitimate good German learner identities, this was a very attractive option in the classroom because it alleviated the tension between complying with Frau Zeller's expectations and the students' own language and investment policies. Put differently, such narrow structures acted as a vehicle of linguistic legitimacy by making it acceptable for students to use the target language.

The analysis of classroom discourse revealed another recurring context of legitimation, namely role-plays. In contrast to the scripts presented above, role-plays were highly under-scaffolded. Frau Zeller limited her directions to assigning the roles and offering German words when students were stuck. In the following abbreviated excerpt, one student, Christopher (a pseudonym) played the German minister of traffic. A picture of a busy junction projected onto the board acted as a prompt for the rest of the class, who assumed the role of townspeople to direct questions at him.

Example 4: Why the car not go?

1. T: We want to know a lot now. What is going on here with this construction

2. site? Yes?

[...]

3. M: Mister President, Mister President!

4. S1: Which town?

5. C: Uh Berlin.

6. [laughter]

7. C: Yes.

8. S2: Why the car not go?*

9. C: It dead is.*

10. S2: Oh no.

11. S3 [quietly]: It is broken. [...]

12. S5: Who in the car $b-$ who in the car be?*

13. C: Uuhmm Germany's president. [...]

14. S7: How late are you?

15. [T laughs.]

16. C: Uhm.

17. S4: No, the car.

18. C: Oh.

19. T: Oh, do you mean the car or the tramway?

20. S5: The car.

21. C [quietly]: Did she ask me how late I was?

22. S4: Yeah.

23. C: Uh fifteen minutes. 
$[\ldots]$

24. S7: Uhh, how fast are the train going?*"

25. C: Uh, one hundred kilometers an hour.

26. [laughter]

27. S6: The tramway is fast.

28. S8: Where is the tramway going?*

29. C: Uhm his parents' house.*

30. [laughter]

31. S8: Alright.

32. S9: Uh what kind of car is that?*

33. T: Aha.

34. C: Uh, Mazda, uh.

35. M: Just call it a Prius.

36. [laughs] Just call it a Prius, it is too big for a Prius.

[...]

37. T: Two more questions.

38. S10: Where is the car going?*

39. C: Nowhere right here [points at curb]. Do you have \{another question?

40. T: One more question\}, one more question.

41. [...]

42. $\mathrm{M}$ [yells]: Minister of traffic!

43. C [rolls eyes, annoyed]: Yes, hi.

44. S11: How many years old is this car?

45. C: Uh, twenty or twenty-one.

46. S12 [quietly]: How do you say what happened to the car?

47. S13 [quietly]: What happens

48. S12: Uh okay, what happens with the car?*

49. C: Uh Uh the [circular motion]

50. T: Wheels?

51. C: The wheels are [explosive sound and hand motion]

52. [laughter] [...]

53. S14: How old is the street?

54. C: How old? Uh [quietly], based on the construction say [to class] ten years old.

55. T: Thank you, thank you Mister Minister.

56. [applause]

(Classroom recording, October 15, 2012)

In contrast to most data, this excerpt features a large amount of German spoken by the students. In total, 16 students were actively involved in this role-play, and 11 questions (lines 4, 8, 12, 14, 24, 28, 32, 38, 44, 48, 53) were asked by the "townspeople". English occurred mostly as a tool for scaffolding and clarifications outside of the actual plot; for example in lines 4647 , when a student (S12) prepared for his question to Christopher by asking his neighbor for language support. Miles (M) was the only student in the class who maintained English throughout this sequence. His English interjections were ignored (lines 3-4), ridiculed (line 36), and evaluated negatively through an eye-roll (line 43). The students' engagement, the amount of German that was voluntarily offered, and the delegitimation of Miles' statements indicate that German was considered the legitimate language for this activity.

What may have facilitated students' language choice was the story Christopher created around the picture of a German politician with a broken car stuck in traffic. Similar to the narrow scripts Frau Zeller provided for mini-dialogues, this plot did not only act as linguistic scaffolding, but also as a tool of legitimation. Assuming their roles as inquisitive townspeople allowed the students to use German in a face-saving way, protected by their roles, rather than running the risk of displaying identities of invested German learners or users. This finding shows that in a context where using a foreign language is generally associated with awkwardness and embarrassment feelings that were also observed by Rampton (2006) in his study of FL German learners - role-play can reverse the norms of legitimacy, at least for a short period of time. Although the importance of both formfocused and meaning-focused language and role play have been recognized in the field of SLA (Bushnell, 2009; Broner \& Tarone, 2001; Cook, 1997), this data points to a new aspect of language learners' play, as legitimizing tool.

Apart from narrowly scaffolded scripts and roleplays, legitimate use of German occurred for the purpose of entertainment. In the following excerpt, a group of four male students volunteered to act out the story of a high school couple, Stefan and Maria, who were attending their homecoming dance. The class was familiar with the story and the students had the text in front of them as well as projected onto the board. The main actors were Christopher (C), Miles (M), Liam (L), and Tom (To) (all pseudonyms).

Example 5: I love you

1. T: Maria and Stefan wanted to go to the homecoming ball.

[...]

2. T [to L]: And what do you say? \{You want to go to the homecoming ball now.

3. L [emphatic]: I love you.] [takes To's arm]

4. C: I love you.

5. [laughter and cheering]

6. C: I love you. [laughs]

7. M: I love, shame on my boy!

8. [laughter]

9. T: Beautiful, he loves her, so what? Hey, but they could not go there

10. because Maria, her father's car, wasn't allowed" to have, so, Maria, you

11. have to ask your* father.

12. L [plays Maria]: You have to ask your" father.

13. T: Liam, ask your* father if you can have the car. $[\ldots]$ 
14. L: Hey Dad, your car have*?

15. T [shouts loudly]: No! What do you say?

16. [loud laughter]

[...]

17. C: You are an irresponsible driver, and yes.

18. [laughter] [...]

19. To [puts his hand on his chest]: I will take one for the team.

20. [loud laughter and talking]

21. To: Hello, mother.

22. M: Hello, no wait [high-pitched voice], hello.

23. [laughter]

24. To: May I, may I, your car?

25. M: No

26. T [loudly]: What is it? What is it?

27. [laughter]

28. To: Uhm car, your car uhm [...] May I your car uhm?

$[\ldots]$

29. T [very loudly]: Shhht the story goes on. Now they wanted to dance the

30. whole night, but they couldn't, they had to return the car.

31. [ $L$ and To make dancing moves.]

32. To: Oh shame, we must go at home.*

33. L: Boom boomboom.

34. [To makes high-pitched sound of squealing tires.]

35. [laughter] [...]

36. T: Then Stefan and Maria said next year we shall?

37. [C and To hug.]

38. C: Shall we in a cab go up?*

39. [laughter] [...]

40. [clapping and high-fives]

41. T: So that is the story of Stefan and Maria.

(Classroom recording, October 3, 2012)

Several points are noteworthy about this excerpt. First, the power balance in the room shifted during this activity. Miles, Christopher, Tom, and Liam (pseudonyms) managed to navigate the activity in a way that allowed them maximum of control of the situation, while at the same time staying on task enough to avoid reprimands from the teacher or a premature end of the activity. They reacted to Frau Zeller's corrective feedback (e.g., lines 13-14) and to her attempts of redirecting them to the plot of the story, but they did so by exploiting the opportunity for humorous interpretations and comments. For instance, Frau Zeller's narrating of the plot ("You want to go to the homecoming ball now", line 2) and her elicitation of output ("What do you say?", line 2), prompted Liam and Christopher to produce with a German phrase ("I love you."), which was not only a very liberal embellishment of the text, but also did not require much linguistic effort on the students' part to produce. However, the answer seemed to be enough for Frau Zeller to refrain from correcting or scolding the students. The student actors walked this fine line between the teacher's and their own agenda throughout the whole skit, a balancing act Pomerantz and Bell (2012) have termed "calibration" (p. 152).

Second, the realization of the activity suggests that five actors and their audience were pursuing the goal of entertaining and being entertained. For example, Liam and Christopher's use of "I love you", possibly and problematically amplified by two boys playing a heterosexual couple, had the hoped-for entertaining effect on the audience: it elicited laughter and cheering. This was a common occurrence. In fact, laughter and/or cheering were present throughout almost all of this activity and frequently dominated the room (lines 5, 8, 16, 18, 23, 27, 35, 39, and 40). These indications of entertainment were almost always sparked by the actors' use of ungrammatical German. For instance, in line 14, Liam undertook an attempt to independently produce a German sentence ("Hey Dad, deine Auto haben*?" - "Hey Dad, your car have*?"), which was met with loud protest from the teacher (line 15) and excessive laughter from the audience (line 16), most likely because of its inaccurate grammar. Later, Christopher's "Sollenwir in ein Taxi auf gehen?*" ("Shall we in a cab go up?*", line 38) failed to become a meaningful sentence and, again, elicited laughter from the audience (line 39).

The general pattern to be observed here is that the German produced by the five actors included switches to English even for very basic words (car in line 14, I in line 19) and barely comprehensible or even meaningless sentences (line 38). This is surprising considering that Christopher, Liam, and Tom were three of the higher-level students in the class. This finding further contrasts with those of Palmer's (2008), Chen's (2010), and Pomerantz' (2008) studies, which describe multilingual students' or language learners' claims of linguistic legitimacy through striving for high proficiency. In the context of this skit, grammatical and lexical accuracy or complexity were not priorities for the students. Quite the opposite, incorrect German appeared to be the legitimate language of this activity, which was established and confirmed through laughter, cheering, and supportive gestures (high-fives, line 40) among the actors and from the audience. This finding relates to Pomerantz and Bell's study (2012) in a college-level Spanish classroom, in which they conceptualize humorous peer interaction as "spaces in which students can experiment with particular classroom identities, critique institutional/ 
instructional norms, and engage in more complex and creative acts of language use" (p. 149). In addition to experimenting with new identities and language use, I argue that the Clearwater students also used humor to challenge existing standards of linguistic legitimacy.

This finding can also be understood through the lens of Norton's (2013) concept of investment, which suggests that learners invest in language learning with the expectation of gaining symbolic and material resources in return. Here, the situation seems to be more complex: rather than fully investing in the German lesson, the students seem to carefully weigh potential gains (e.g., language, credentials) with potential losses (e.g., face, status) and navigate this tension with the help of performances of (low level) German.

In sum, the analysis of data from this German classroom shows that German was legitimate when it was highly scripted, produced in role-plays, or used with the purpose to entertain. All of these are features of performances, which students used to construct their "uninvestment". Whether through scripts, roles, or humor, an important goal for the students was to construct identities of non-commitment or noninvestment, which severely limited their opportunities for complex and rich output, language use and development, and building of their own identities as legitimate and multilingual users of German.

These observed dynamics in Frau Zeller's classroom have to be understood within the wider context of societal discourses that delegitimize FL learning and education. As Kinginger (2004) explains,

[i]n the United States, foreign language learning is normally construed as an academic pursuit which is optional at best, and is not seen as a matter of survival... Perhaps this occurs because of a widespread and deeply held suspicion toward multilingualism per se ..., since a foreign language education policy would require an unambiguous and unbiased statement on the value of multilingual competence. (p. 221)

As long as multilingualism or the use of non-English languages remains indexed as "foreign" or even "nonAmerican" to the greater society (Kinginger, 2004; Pavlenko, 2004), FL learners will find it difficult to use their languages flexibly and legitimately and build legitimate multilingual identities. This idea is also echoed by Kramsch (2012), who adds monolingualism to the list of social factors that determine one's legitimacy in the U.S.,

a country in which supposedly "anything is possible” but conversely anything can also become impossible at any time, depending on how one is perceived along the usual axes of race, ethnicity, social class, geographical origins, political learnings, gender and sexual orientation - and, we would now have to add, monolingualism (p. 112).

That being said, classroom discourses are not merely at the mercy of societal ideologies and hegemonies, they are also sites of opposition and nonconformity. Given the strategies the students already have in establishing legitimacy for their language use, bringing those to the fore, building on them, and educating teachers to do so, is both possible and necessary to promote FL learners and multilingual students' linguistic legitimacy in their immediate or larger environment.

\section{Conclusions and Implications}

The findings of this study illustrate the complexities learners of German face when claiming legitimacy for using their target language in their German classroom. In regard to theoretical implications to be inferred from this study, the concept of linguistic legitimacy was well suited to capture the processes of negotiation that the Clearwater students engaged in to establish acceptance and validation for their (target) language use. The study illustrates negotiations of linguistic legitimacy, but more research is needed to expand this work and establish a comprehensive model of linguistic legitimacy, which can then be used to analyze the experience of multilingual learners in various contexts. As a next step, what is needed is a concept of linguistic legitimacy that outlines its intersections with race, ethnicity, gender, religion, class, ability, sexual orientation, and other social factors. Understanding these connections would prepare the way for building language curricula that promote linguistic legitimacy for all language learners.

The findings of this study also have important implications for teaching and teacher education. In order for students to be successful FL learners, they need to be able to claim legitimacy for their language use. This goal is distinct from acquiring proficiency and, as the data of this study shows, can even run counter to it.

Teaching linguistic legitimacy can occur on several levels. The following list is a starting point for teachers and teacher educators who seek to encourage their learners to establish linguistic legitimacy and make use of their linguistic resources:

1. Explicit teaching and practice of legitimacy claims 
in interaction.

In situations when target language use seems illegitimate, it is helpful for language learners to have strategies for claiming that legitimacy. Legitimacy-based language instruction could, for instance, provide learners with language for legitimacy claims and granting legitimacy and practice such strategies in order to equip them for challenging discourses and policies of linguistic illegitimacy in interaction.

2. Critical analysis of language ideologies and policies within relevant contexts.

The more language learners become aware of the ideologies and policies that permeate their language learning environment, the better they will be equipped to critically evaluate them and adjust their language practices accordingly. For example, a higher awareness of their own implicit English policy, or the hegemonic role of English in the United States might have allowed or even encouraged the Clearwater students to step outside these confines and find a new approach to using German.

3. Fostering identity-building in the FL classroom. Students in FL classrooms can greatly benefit from pedagogical approaches which promote investment and legitimacy through identity work. Recognizing foreign languages as avenues that can lead to new identities or gaining access to new (imagined) communities can encourage students to step out of their (performed) non-investment and thus push them into a space of investment and legitimacy that is more conducive to language acquisition. In all, this study provided evidence that FL classrooms are spaces where identities are constructed and linguistic legitimacy is negotiated. In addressing these processes in ways that empower FL learners, FL teachers and teacher educators can help them to become confident and competent users of their target languages.

\section{References}

Bourdieu, P. (1977). The economics of linguistic exchanges. Social Science. Information, 16(6), 645658.

Broner, M. A., \& Tarone, E. E. (2001). Is it fun? Language play in a fifth grade Spanish immersion classroom. The Modern Language Journal, 85(3), 363-379.

Bushnell, C. (2009). 'Lego my keego!': An analysis of language play in a beginning Japanese as a foreign language classroom. Applied Linguistics, 30(1), 49-
69.

Center for Applied Second Language Studies (CASLS). (2010). What proficiency do high school students achieve? Retrieved in January 2016 from https://casls.uoregon.edu/wp-content/ themes/caslstheme/pdfs/tenquestions/ TBQProficiencyResults.pdf

Chen, X. (2010). Identity construction and negotiation within and across school communities: The case of one English-as-a-New-Language (ENL) student. Journal of Language, Identity \& Education, 9(3), 163179.

Cook, G. (1997). Language play, language learning. ELT journal, 51(3), 224-231.

Corbin, J. M. , \& Strauss, A. L. (2015). Basics of qualitative research: Techniques and procedures for developing grounded theory. Thousand Oaks, CA: Sage.

Darvin, R., \& Norton, B. (2015). Identity and a model of investment in applied linguistics. Annual Review of Applied Linguistics, 35, 36-56.

De Costa, P. I. (2011). Using language ideology and positioning to broaden the SLA learner beliefs landscape: The case of an ESL learner from China. System, 39(3), 347-358.

Gao, X., Cheng, H., \& Kelly, P. (2008). Supplementing an uncertain investment? Mainland Chinese students practising English together in Hong Kong. Journal of Asian Pacific Communication, 18(1), 9-29.

$\mathrm{Gu}, \mathrm{M}$. (2008). Identity construction and investment transformation College students from nonurban areas in China. Journal of Asian Pacific Communication, 18(1), 49-70.

Heller, M. (1995). Language choice, social institutions, and symbolic domination. Language in Society, 24(3), 373-405.

Heller, M. (1996). Legitimate language in a multilingual school. Linguistics and Education, 8, 139-157.

Heller, M. (2006). Linguistic minorities and modernity: A sociolinguistic ethnography (2nd ed.). New York, NY: Continuum.

Hinnenkamp, V. (2005). Semilingualism, double monolingualism and blurred genres - on (not) speaking a legitimate language. In F.-O. Radtke (Ed.). Migration. Retrieved February, 2014 from http://www.sowi-onlinejournal.de/2005-1/index. html

Kinginger, C. (2004). Alice doesn't live here anymore: Foreign language learning and identity reconstruction. In A. Pavlenko \& A. Blackledge (Eds.). Negotiation of identities in multilingual contexts (pp. 219-242). Clevedon, UK: Multilingual Matters.

Kubota, R. (2011). Questioning linguistic instrumentalism: English, neoliberalism, and language tests in Japan. Linguistics and Education, 
22(3), 248-260.

Kramsch, C. (2012). Authenticity and legitimacy in multilingual SLA. Critical Multilingualism Studies, $1(1), 107-128$.

Leki, I. (2001). "A narrow thinking system": NonnativeEnglish-speaking students in group projects across the curriculum. TESOL Quarterly, 35(1), 39-67.

Low, B., Sarkar, M., \& Winer, L. (2009). 'Ch'us mon proper Bescherelle': Challenges from the HipHop nation to the Quebec nation. Journal of Sociolinguistics, 13(1), 59-82

Morita, N. (2004). Negotiating participation and identity in second language academic communities. TESOL Quarterly, 38(4), 573-603.

Norton, B. (2000). Identity and language learning: Gender, ethnicity and educational change. Harlow, UK: Pearson Education Limited.

Norton, B. (2013). Identity and language learning: Extending the conversation. Bristol, UK: Multilingual Matters.

Norton Peirce, B. (1995). Social identity, investment, and language learning. TESOL Quarterly, 29(1), 9-31.

Palmer, D. K. (2008). Building and destroying students' 'academic identities': The power of discourse in a two-way immersion classroom. International Journal of Qualitative Studies in Education, 21(6), 647-667.

Park, J. S. Y. (2010). Naturalization of competence and the neoliberal subject: Success stories of English language learning in the Korean conservative press. Journal of Linguistic Anthropology, 20(1), 22-38.

Pavlenko, A. (2004). The making of an American": Negotiation of identities at the turn of the twentieth century. In A. Pavlenko \& A. Blackledge (Eds.), Negotiation of identities in multilingual contexts (pp. 34-67). Clevedon, UK: Multilingual Matters.

Pavlenko,A., \&Blackledge,A.(Eds.). (2004). Negotiation of identities in multilingual contexts. Clevedon, UK: Multilingual Matters.

Pomerantz, A., \& Bell, N. D. (2011). Humor as safe house in the foreign language classroom. The Modern Language Journal, 95(s1), 148-161.

Pittaway, D. S. (2004). Investment and second language acquisition. Critical Inquiry in Language Studies,
1(4), 203-218.

Pomerantz, A. (2002). Language ideologies and the production of identities: Spanish as a resource for participation in a multilingual marketplace. Multilingua, 21, 275-302.

Pomerantz, A. (2008). "Tú necesitas preguntaren Español": Negotiating good language learner identity in a Spanish classroom. Journal of Language, Identity, and Education, 7(3-4), 253-271.

Rampton, B. (1999). Crossing. Journal of Linguistic Anthropology, 9(1/2), 54-56.

Rampton, B. (2014). Crossing: Language and ethnicity among adolescents (2nd ed.). London, UK: Routledge.

Rampton, B. (2006). Language in late modernity: Interaction in an urban school. Cambridge, UK: Cambridge University Press.

Reagan, T. (2016). The conceptualization of language legitimacy. Critical Inquiry in Language Studies, 13(1), 1-19.

Swain, M. (1995). Three functions of output in second language learning. Principle and Practice in Applied Linguistics: Studies in Honour of H. G. Widdowson, 2(3), 125-144.

Talmy, S. (2008). The cultural productions of the ESL student at Tradewinds High: Contingency, multidirectionality, and identity in L2 socialization. Applied Linguistics, 29(4), 619-644.

Trent, J. (2008). Promoting investment by Chinese learners in classroom discourse integrating content and language in the undergraduate classroom. Journal of Asian Pacific Communication, 18(1), 3048.

Van Leeuwen, T. (2008). Discourse and practice: New tools for critical discourse analysis. New York, NY: Oxford University Press.

Van Leeuwen, T. (2007). Legitimation in discourse and communication. Discourse \& Communication, 1(1), 91-112.

Van Leeuwen, T., \& Wodak, R. (1999). Legitimizing immigration control: A discourse-historical analysis. Discourse Studies, 1(1), 83-118.

Wodak, R., \& Van Leeuwen, T. (2002). Discourses of un/employment in Europe: The Austrian case. Text, 22(3), 345-368. 


\section{JOHANA ENNSER-KANANEN}

\section{Appendix A}

\section{Transcription conventions}

\begin{tabular}{ll}
\hline \multicolumn{1}{c}{ Abbreviation/Sign } & \multicolumn{1}{c}{ Meaning } \\
\hline S1, S2, etc. & student one, student two, etc. \\
& $\begin{array}{l}\text { (Only students who spoke three times or more within one segment } \\
\text { are represented by pseudonyms. })\end{array}$ \\
\hline $\mathrm{T}$ & teacher \\
\hline$!$ & increased volume \\
\hline$?$ & rising intonation, e.g. in a question \\
\hline \{ $]$ & Overlap \\
\hline [laughter]; [eagerly]; [shakes head], etc. & $\begin{array}{l}\text { additional information about the speaker, e.g. non-verbal cues, tone, } \\
\text { action, or motion }\end{array}$ \\
\hline Italics & words or sentences that have been translated from German \\
\hline
\end{tabular}

